\title{
PERENCANAAN ARSITEKTUR SISTEM INFORMASI PEMBANGUNAN INFRASTRUKTUR DENGAN METODE ENTERPRISE ARCHITECTURE PLANNING MENGGUNAKAN TOGAF-ADM FRAMEWORK
}

(Studi Kasus : Dinas Pekerjaan Umum dan Penataan Ruang Kab. Indramayu)

\author{
Mukhsin \\ Universitas Wiralodra, Jln. Ir. H. Juanda Km 3 Indramayu, mukhsin.ft@unwir.ac.id
}

\begin{abstract}
ABSTRAK
Dinas Pekerjaan Umum dan Penataan Ruang (PUPR) Kabupaten Indramayu adalah instansi pemerintahan yang bergerak di bidang infrastruktur/konstruksi gedung dan bangunan. Salah satu strategi yang penting dalam menghadapi perkembangan teknologi informasi adalah pemanfaatan dan peningkatan dukungan sistem informasi bagi dinas atau instansi. Keselarasan penerapan sistem informasi dengan kebutuhan organisasi sebagai sebuah dinas/instansi yang mengutamakan pelayanan masyarakat dalam bidang infrastruktur pembangunan hanya mampu dijawab dengan memperhatikan faktor integritas didalam pengembangannya. Tujuan integritas sistem informasi dengan kebutuhan organisasi sebenarnya adalah untuk mengurangi kesenjangan yang terjadi dalam proses pengembangan sistem. Untuk menurunkan kesenjangan tersebut, maka diperlukan sebuah paradigma dalam merencanakan, merancang, dan mengelola sistem informasi. Paradigma atau metodologi yang digunakan dalam perencanaan arsitektur sistem informasi pembangunan infrastruktur ini menggunakan TOGAF-ADM. Tahapan dalam pengembangan sistem informasi dengan memodelkan arsitektur bisnis, arsitektur data, arsitektur aplikasi dan arsitektur teknologi sesuai dengan kerangka kerja TOGAF-ADM. Output dari tahapan ini akan menghasilkan sebuah acuan (cetak biru/blue print) oleh dinas/instansi untuk mencapai tujuan strateginya.
\end{abstract}

\section{Kata Kunci : Sistem Informasi, Arsitektur, Pembangunan Infrastruktur, TOGAF- ADM.}

\begin{abstract}
Department of Public Works and Spatial Planning (PUPR) of Indramayu Regency are government agencies engaged in infrastructure / building and building construction. One important strategy in dealing with the development of information technology is the use and enhancement of information system support for agencies or agencies. The alignment of the application of information systems with the needs of the organization as an agency that prioritizes community service in the field of development infrastructure is only able to be answered by paying attention to the integrity factor in its development. The purpose of information system integrity with the actual needs of the organization is to reduce the gap that occurs in the system development process. To reduce the gap, a paradigm is needed in planning, designing, and managing information systems. The paradigm or methodology used in the planning of information systems infrastructure construction infrastructure uses TOGAF-ADM. Stages in the development of information systems by modeling business architecture, data architecture, application architecture and technology architecture in accordance with the TOGAF-ADM framework. The output of this stage will produce a reference (blueprint) by the agency to achieve its strategic objectives.
\end{abstract}


Keywords : Information System, Architectural, Infrastructure development, TOGAFADM.

\section{PENDAHULUAN}

Dinas Pekerjaan Umum dan Penataan Ruang (PUPR) Kabupaten Indramayu sebagai pelaksana kewenangan Pemerintah Daerah dibidang pembangunan infrastruktur adalah instansi pemerintahan yang bergerak dibidang konstruksi bangunan sesuai dengan Peraturan Bupati Kabupaten Indramayu Nomor 38 Tahun 20016 tentang Organisasi dan Tata Kerja Dinas Pekerjaan Umum dan Penataan Ruang (PUPR) Kabupaten Indramayu. Pelaksanaan kegiatan Pemerintah Daerah pada hakekatnya merupakan upaya mewujudkan tercapainya masyarakat yang sejahtera, adil dan makmur. Untuk mencapai tujuan dimaksud, segala upaya yang dilakukan tetap berdasarkan norma dan hukum yang berlaku. Salah satu upaya yang dilakukan saat ini adalah mendorong terciptanya penyelenggaraan pemerintahan yang baik good governance dengan ciri semua kegiatan terukur, dapat dipertanggungjawabkan serta bersih dari korupsi, kolusi dan nepotisme.

Untuk meningkatkan kualitas pelayanan, perlu adanya sebuah sistem informasi yang mampu memonitoring dan membantu proses kinerja dari sebuah instansi. Salah satu faktor pendorong peningkatan kualitas layanan adalah pemanfaatan sistem informasi dengan kualitas fungsi pelayanan yang lebih baik dan saling terintegrasi. Belum adanya keseragaman pemahaman dan komitmen dalam memandang teknologi informasi di setiap level (pengambil keputusan maupun operasional), serta kebijakan yang diambil masih bersifat persial dalam pengelolaan teknologi informasi mengakibatkan pengelolaan sistem informasi masih bersifat sektoral, serta perencanaan dan operasional tidak tersusun dengan benar.

Suatu sistem informasi sebuah Instansi harus dibangun dengan perencanaan yang baik. Kurangnya perencanaan di dalam proses pengembangan sistem informasi yang tepat akan menghambat dalam melengkapi arah strategi suatu Instansi. Sistem Informasi yang baik harus melihat dari berbagai sudut pandang dalam suatu pengembangan sistem, dimulai dari mendefinisikan arsitektur data, arsitektur aplikasi serta mendefinisikan arsitektur teknologi yang mendukung jalannya sistem informasi tersebut.

Dalam pengembangan sistem informasi, faktor integrasi juga perlu diperhatikan untuk mengurangi kesenjangan dalam proses pengembangan sistem. Untuk mengurangi kesenjangan tersebut perlu adanya perbaikan business process serta perancangan teknologi sistem informasi seperti perancangan infrastruktur informasi (data), perancangan infrastruktur aplikasi dan perancangan infrastruktur jaringan (teknologi) sehingga Instansi 
berkewajiban mengembangkan dan menerapkan serta memanfaatkan kemajuan teknologi informasi untuk meningkatkan kemampuan mengelola enterprise-nya.

\section{METODE PENELITIAN}

Penelitian ini menggunakan pendekatan deskriptif studi kasus. Untuk memahami fenomena yang sudah terfokus secara lebih mendalam, maka metode yang digunakan dalam penelitian adalah metode kuantitatif, dikarenakan fenomena di lapangan bersifat menyeluruh, kompleks, dinamis dan penuh makna.

Adapun tujuan dari penelitian ini adalah sebagai berikut:

1) Merencanakan arsitektur sistem informasi Pembangunan Infrastruktut berbasis TI untuk mendukung visi dan misi Dinas PUPR Kab. Indramayu;

2) Merencanakan arsitektur sistem informasi Pembangunan Infrastruktut berbasis TI yang sesuai dengan proses bisnis Dinas PUPR Kab. Indramayu;

3) Merencanakan arsitektur sistem informasi Pembangunan Infrastruktut berbasis TI yang sesuai dengan teknologi yang berkembang saat ini.

Data yang diperoleh hasil pengamatan langsung adalah permasalahan dan keadaan arsitektur sistem informasi saat ini, yaitu model keadaan arsitektur bisnis, arsitektur data, arsitektur aplikasi, arsitektur teknologi dan data yang dihasilkan dari wawancara dengan pimpinan dan pegawai yang behubungan dengan Teknologi Informasi. selanjutnya dipilih enterprise architecture framework yang akan dijadikan sebagai acuan dengan membandingkan antara kerangka-kerangka arsitektur yang digunakan pada saat ini dan dipilih satu yang sesuai dengan kondisi dan kebutuhan enterprise.

Framework yang dipilih adalah TOGAF-ADM, kemudian dikembangkan suatu sistem informasi sesuai dengan tahapan-tahapan TOGAF-ADM yang hasilnya dijadikan sebagai acuan baku (blue print) pengembangan sistem informasi yang akan diterapkan. Metodologi Penelitian yang dilakukan dalam perancangan sistem informasi pembangunan infrastruktur Dinas PUPR Kabupaten Indramayu ini berdasarkan langkah-langkah kerangka kerja (framework) yang dipilih, seperti yang diilustrasikan pada gambar sebagai berikut : 


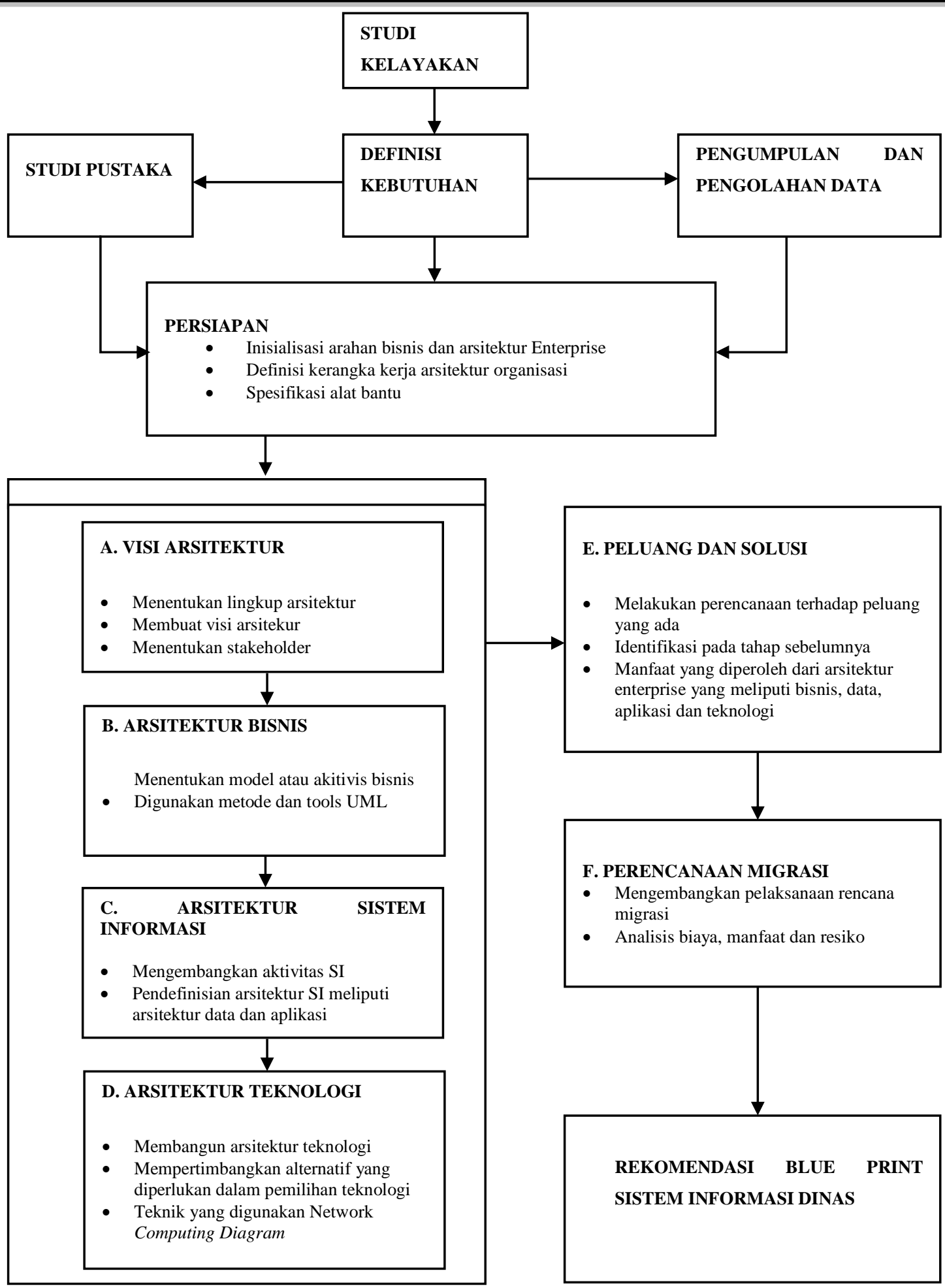

Gambar 2. Metodologi Penelitian

\section{HASIL DAN PEMBAHASAN}

Model prinsip arsitektur sistem informasi pembangunan infrastruktur Dinas PUPR Kabupaten Indramayu dibagi menjadi dua bagian yaitu arsitektur teknologi informasi dan arsitektur bisnis. Arsitektur teknologi informasi meliputi komponen infrastruktur teknologi 
informasi, data dan aplikasi sedangkan arsitektur bisnis terdiri dari komponen-komponen kemampuan organisasi, keadaan organisasi serta proses bisnis dan informasi. Arsitektur teknologi informasi sebagai pendukung arsitektur bisnis untuk mencapai tujuan, visi, strategi dari arsitektur sistem informasi pembangunan infrastruktur Dinas PUPR Kabupaten Indramayu.

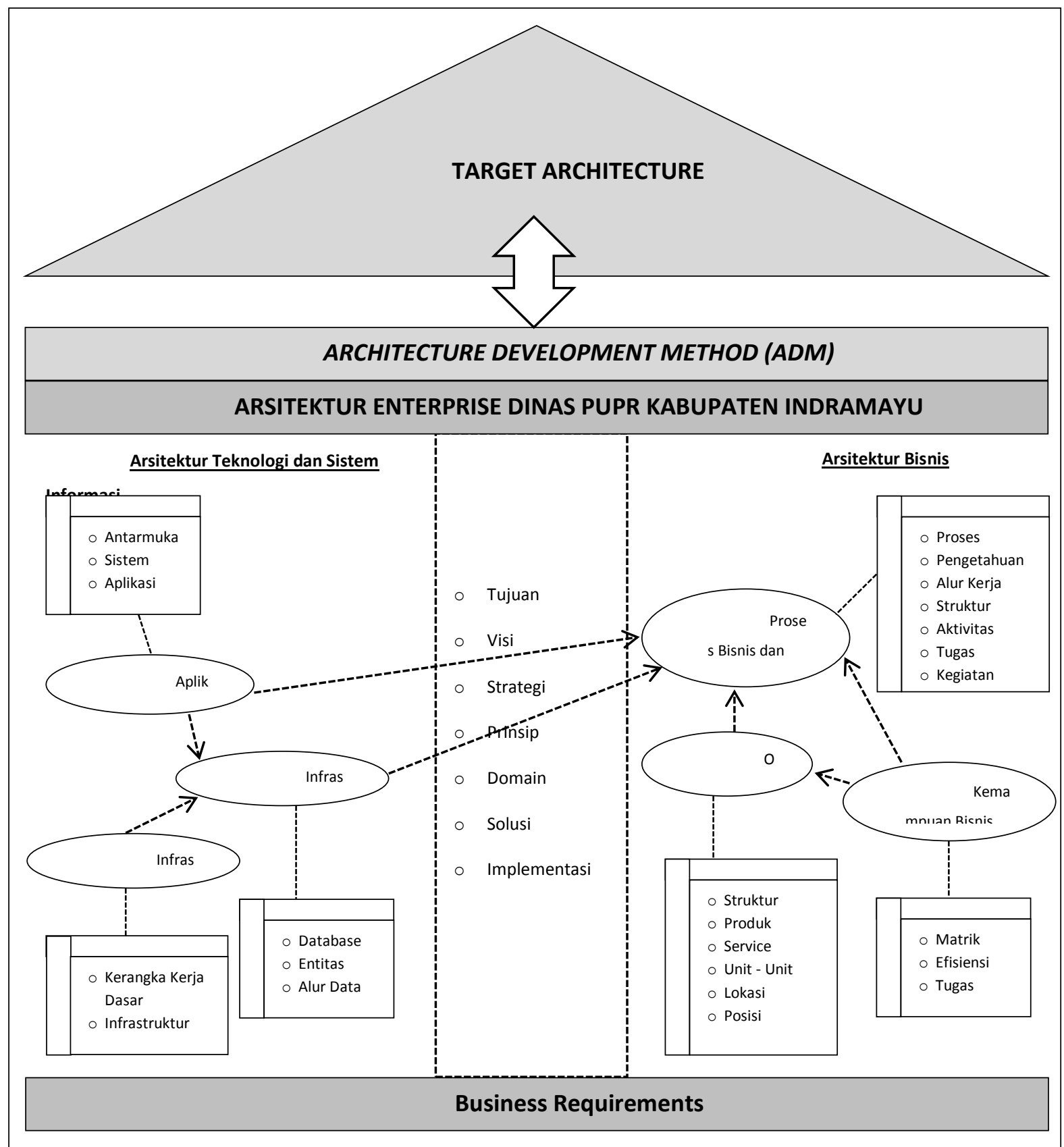

Gambar 3. Model Prinsip Arsitektur Sistem Informasi Pembangunan Infrastruktur 


\subsection{Visi Arsitektur}

Visi Dinas PUPR Kabupaten Indramayu adalah Terwujudnya Dinas PUPR yang mampu mendorong terciptanya permukiman dan penataan ruang yang layak, serasi serta berbasis pelestarian lingkungan.

Penentuan visi arsitektur organisasi, dilakukan dengan mendefinisikan ruang lingkup arsitekur termasuk arsitektur bisnis, arsitektur sistem informasi dan arsitektur teknologi. Visi arsitektur organisasi yang ingin dicapai Dinas PUPR Kabupaten Indramayu adalah "Terciptanya Integritas Teknologi Informasi Dalam Sistem Informasi Yang Dinamis“. Dengan visi tersebut dapat mendukung fungsi dan proses bisnis tujuan oraganisasi sehingga dapat terlaksana dengan baik. Integritas teknologi dan sistem informasi pembangunan infrastruktur pada Dinas PUPR Kabupaten Indramayu akan mendukung jalannya fungsi bisnis organisasi secara menyeluruh di tingkat manajerial dan operasional.

\subsection{Model Arsitektur Bisnis}

Aktivitas Dinas PUPR Kabupaten Indramayu secara manajerial maupun operasional berpedoman kepada ketentuan Peraturan Bupati Indramayu Nomor 38 Tahun 20016 dan SOP dinas yang telah ditetapkan, dari analisis yang dilakukan dapat diidentifikasi aktivitas utama dan aktivitas pendukung dari Dinas PUPR Kabupaten Indramayu.

Aktivitas yang berjalan dalam pembangunan infrastruktur yang digambarkan dalam bentuk rantai nilai. Dalam rantai nilai ini diuraikan masing-masing aktivitas utama dan aktivitas pendukung pembangunan infrastruktur.

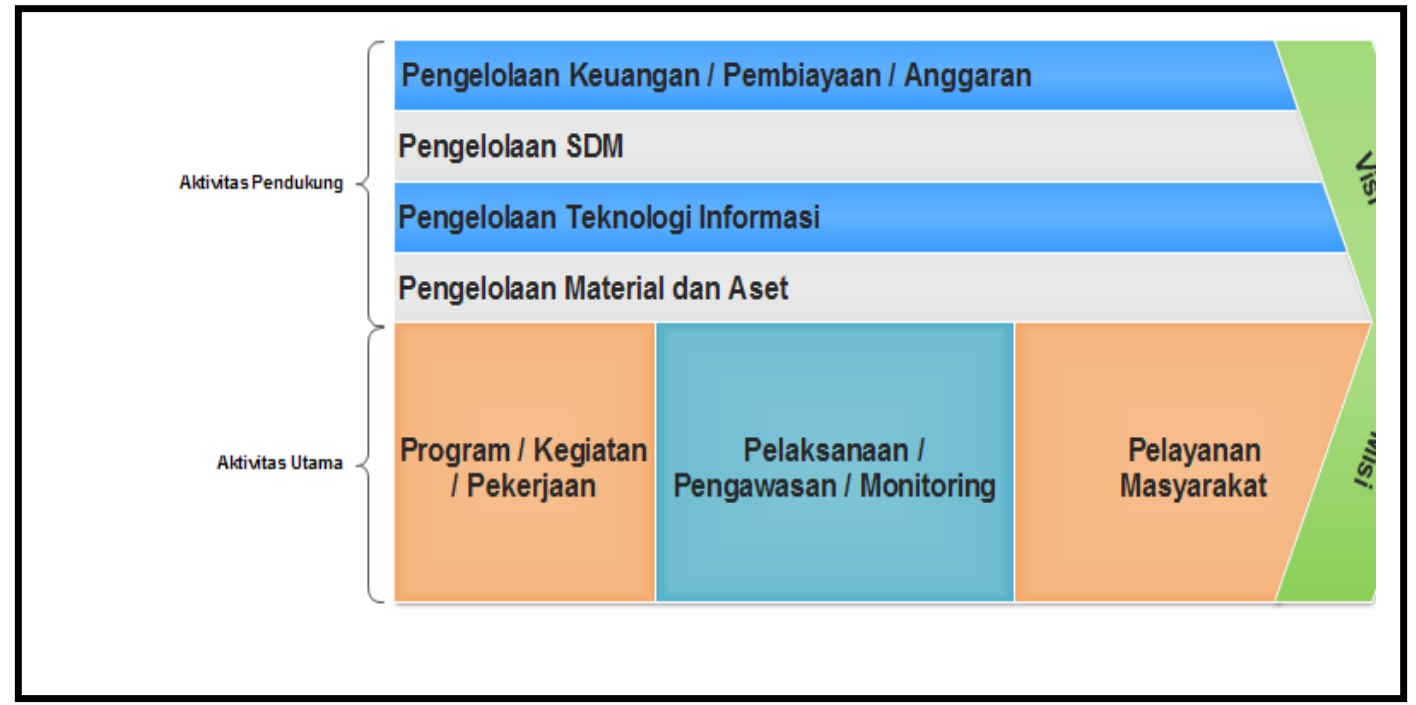

Gambar 4. Rantai Nilai Pembangunan Infrastruktur 
Berdasarkan bentuk rantai nilai diatas, dapat ditentukan masing-masing fungsi bisnis dalam daftar katalog yang diidentifikasi dari proses-proses bisnis yang terjadi pada masing-masing fungsi bisnis.

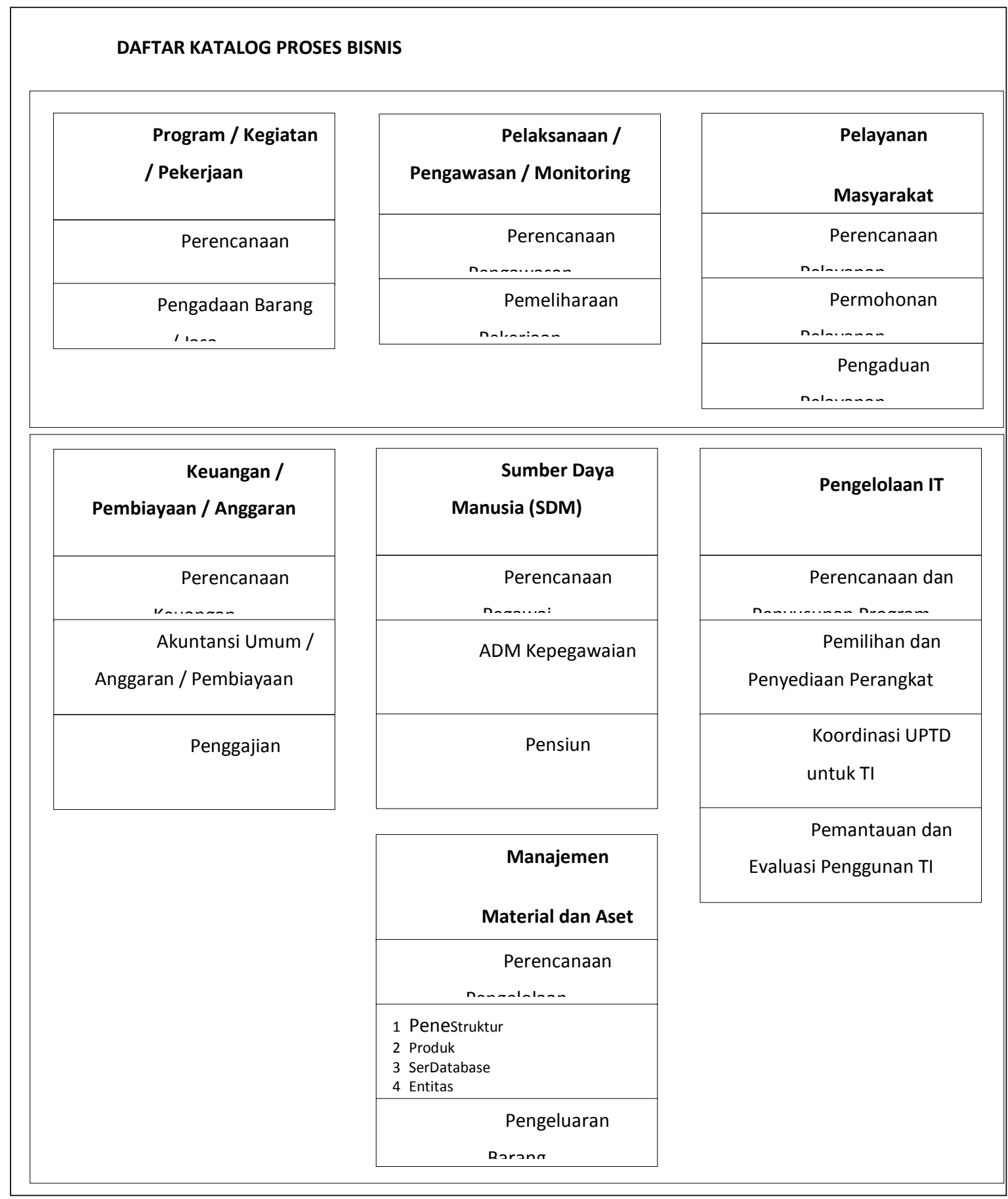

Gambar 5. Daftar Katalog Proses Bisnis Pembangunan Infrastruktur

Dalam perancangan arsitektur bisnis untuk mendefinisikan fungsi bisnis dapat digambarkan dengan menggunakan Use Case Package Diagram yang merupakan ilustrasi model arsitektur bisnis yang berjalan pada Dinas PUPR Kabupaten Indramayu baik fungsi bisnis utama maupun fungsi bisnis pendukungnya. 

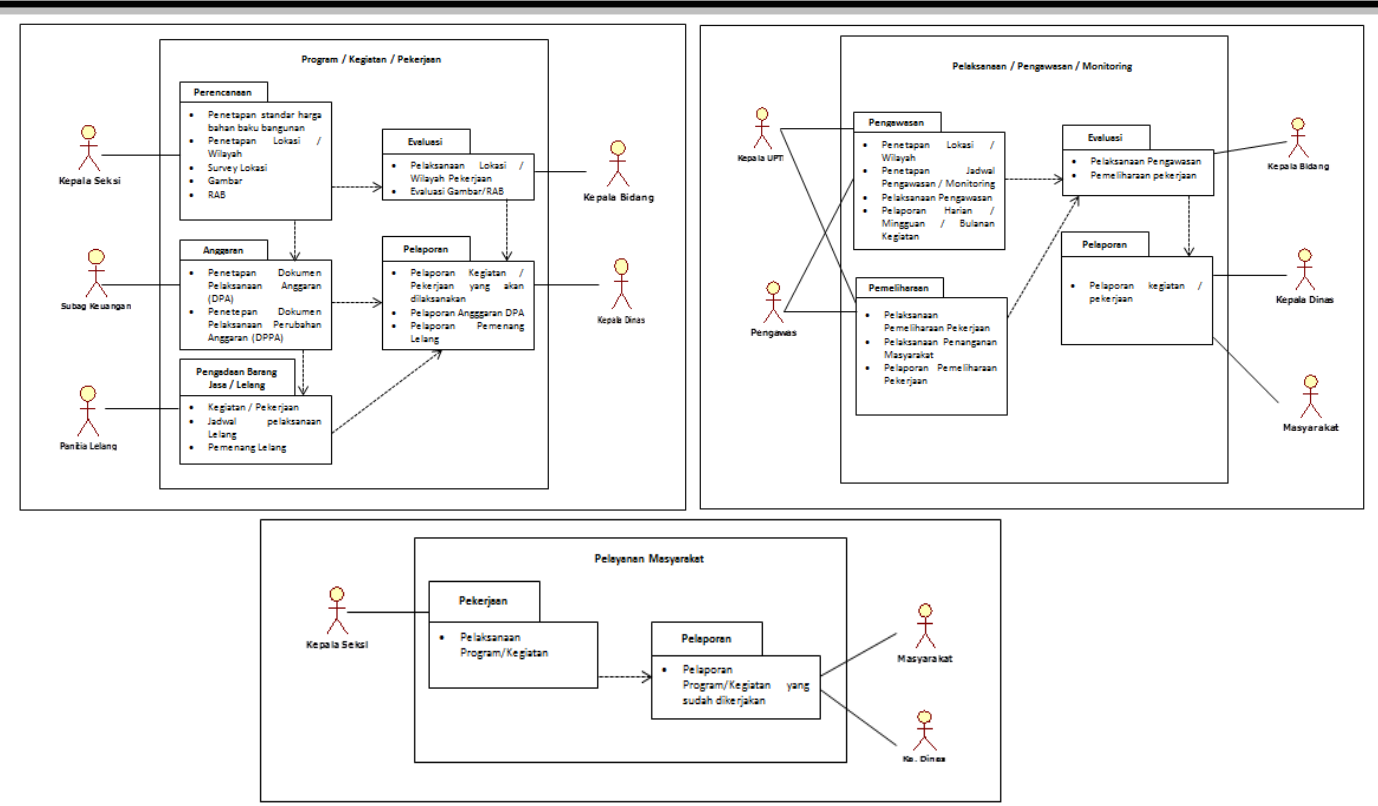

Gambar 6. Model Arsitektur Bisnis Aktivitas Utama

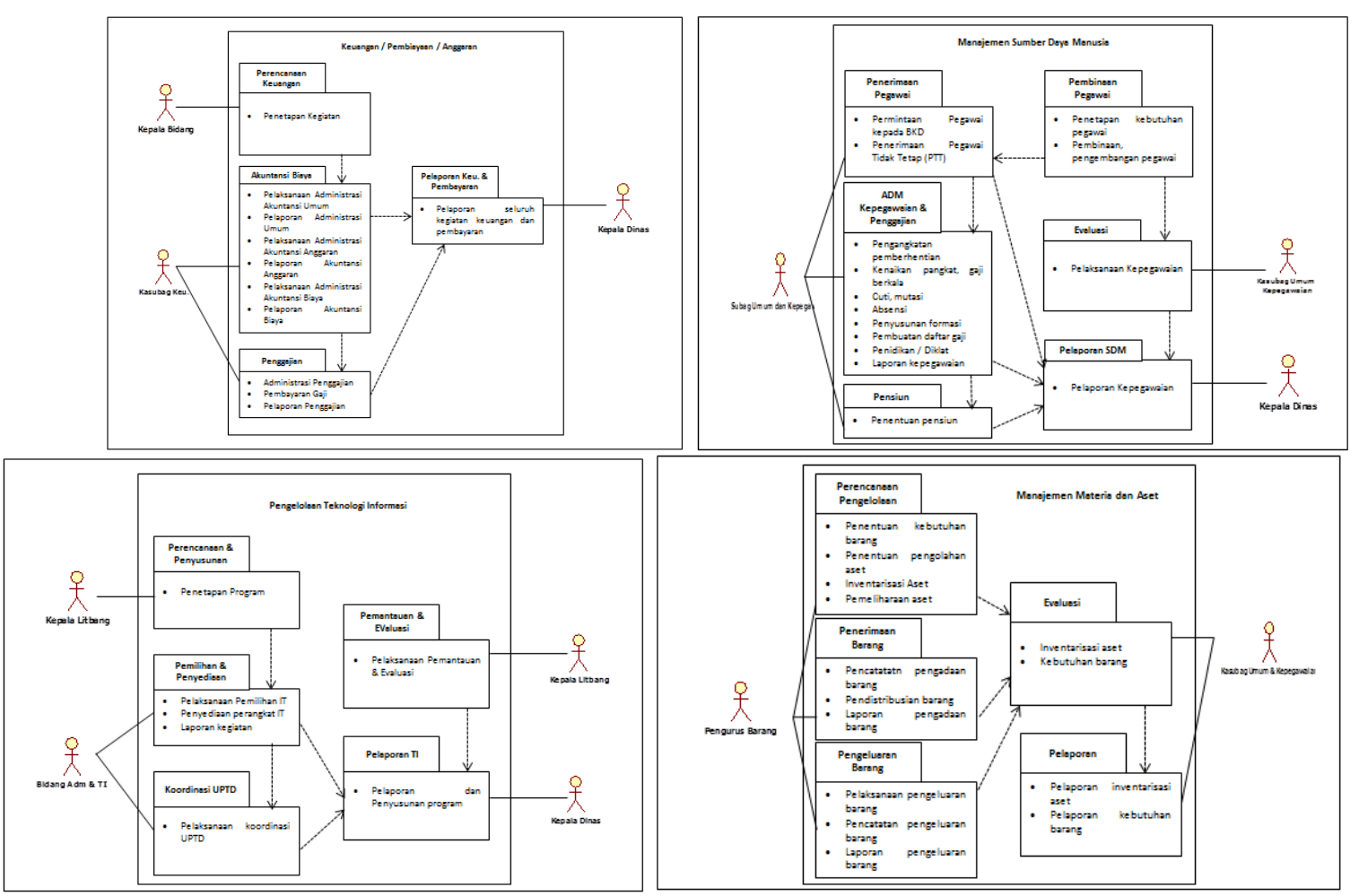

Gambar 7. Model Arsitektur Bisnis Aktivitas Pendukung

\subsection{Model Arsitektur Sistem Informasi}

Model arsitektur sistem informasi meliputi model arsitektur data dan model arsitektur aplikasi. Arsitektur data lebih memfokuskan pada bagaimana data digunakan untuk kebutuhan fungsi bisnis, proses dan layanan. Sedangkan arsitektur aplikasi berasosiasi dengan data dan pengguna sistem tersebut.

\subsubsection{Model Arsitektur Data}


Pembuatan model arsitektur data dengan melakukan identifikasi data yang mendukung fungsi-fungsi bisnis yang terdefinisi dalam model bisnis dengan mendefinisikan arsitektur data yaitu dengan mendaftarkan kandidat entitas data yang ada pada Dinas PUPR Kabupaten Indramayu. Beberapa entitas yang ada pada fungsi bisnis Dinas PUPR Kabupaten Indramayu ditunjukkan pada tabel.

Tabel 2. Kandidat Entitas Data

\begin{tabular}{|c|l|l|}
\hline No. & \multicolumn{1}{|c|}{ Entitas Fungsi Bisnis } & \multicolumn{1}{c|}{ Entitas Data } \\
\hline 1. & Program / Kegiatan / Pekerjaan & $\begin{array}{l}\text { PPTK (Pejabat Pelaksana Teknis Kegiatan) / } \\
\text { Kepala Seksi , KPA (Kuasa Pengguna Anggaran) } \\
\text { / Kepala Bidang, Kode Program, Kode Kegiatan, } \\
\text { Kode Rekening Belanja (Pekerjaan), Kepala } \\
\text { Dinas / PA (Pengguna Anggaran) }\end{array}$ \\
\hline 2. & $\begin{array}{l}\text { Pelaksanaan / Pengawasan / } \\
\text { Monitoring }\end{array}$ & $\begin{array}{l}\text { Pengawas, Kegiatan, Lokasi/Wilayah, Laporan, } \\
\text { PPTK (Pejabat Pelaksana Teknis Kegiatan), } \\
\text { Kepala UPTD, Kepala Dinas / PA (Pengguna } \\
\text { Anggaran) }\end{array}$ \\
\hline 3. & Pelayanan Masyarakat & $\begin{array}{l}\text { PPTK (Pejabat Pelaksana Teknis Kegiata), } \\
\text { Pengawas, Kegiatan, Lokasi/Wilayah, } \\
\text { Permohonan Masyarakat / Proposal, Kepala } \\
\text { Bidang (KPA), Kepala Dinas (PA) }\end{array}$ \\
\hline 4. & $\begin{array}{l}\text { Manajemen Keuangan / } \\
\text { Pembiayaan / Anggaran }\end{array}$ & $\begin{array}{l}\text { Pegawai, Kasubag Keuangan, Gaji, Anggaran, } \\
\text { Biaya Umum, Laporan, Kepala Dinas. }\end{array}$ \\
\hline 5. & $\begin{array}{l}\text { Manajemen Sumber Daya } \\
\text { Manusia }\end{array}$ & $\begin{array}{l}\text { Pegawai, Kebutuhan SDM, Pengelolaan SDM, } \\
\text { Diklat, Promosi, Mutasi, Ijin Cuti, Absensi, } \\
\text { Pensiun, Laporan. }\end{array}$ \\
\hline 6 & $\begin{array}{l}\text { Manajemen Teknologi } \\
\text { Informasi }\end{array}$ & $\begin{array}{l}\text { Program Penelitian Teknologi Informasi, } \\
\text { Koordinasi UPTD (Unit Pelaksana Teknis } \\
\text { Dinas), Pemantauan dan Evaluasi, Pelaporan. }\end{array}$ \\
\hline 7. & Manajemen Material dan Aset & $\begin{array}{l}\text { Pengajuan Kebutuhan, Pengelolaan Aset, } \\
\text { Pengguna, Laporan. }\end{array}$ \\
\hline
\end{tabular}

Setelah fungsi-fungsi bisnis diidentifikasi pada model arsitektur bisnis, tahap selanjutnya adalah mendefinisikan arsitektur data dengan mendaftarkan kandidat entitas data yang diilustrasikan pada hubungan antar kelas pada gambar kelas data dari masingmasing data yang telah teridentifikasi. Hubungan antar kelas data diilustrasikan dengan menggunakan diagram kelas sebagai berikut: 


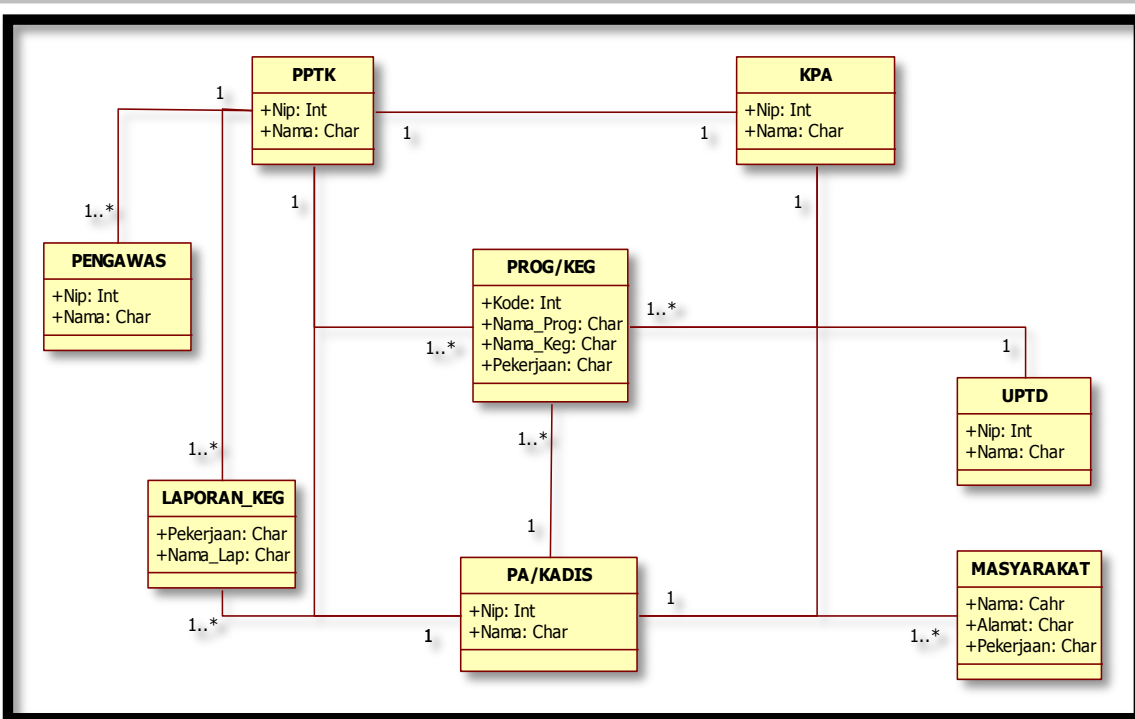

Gambar 8. Model Arsitektur Data Aktivitas Utama

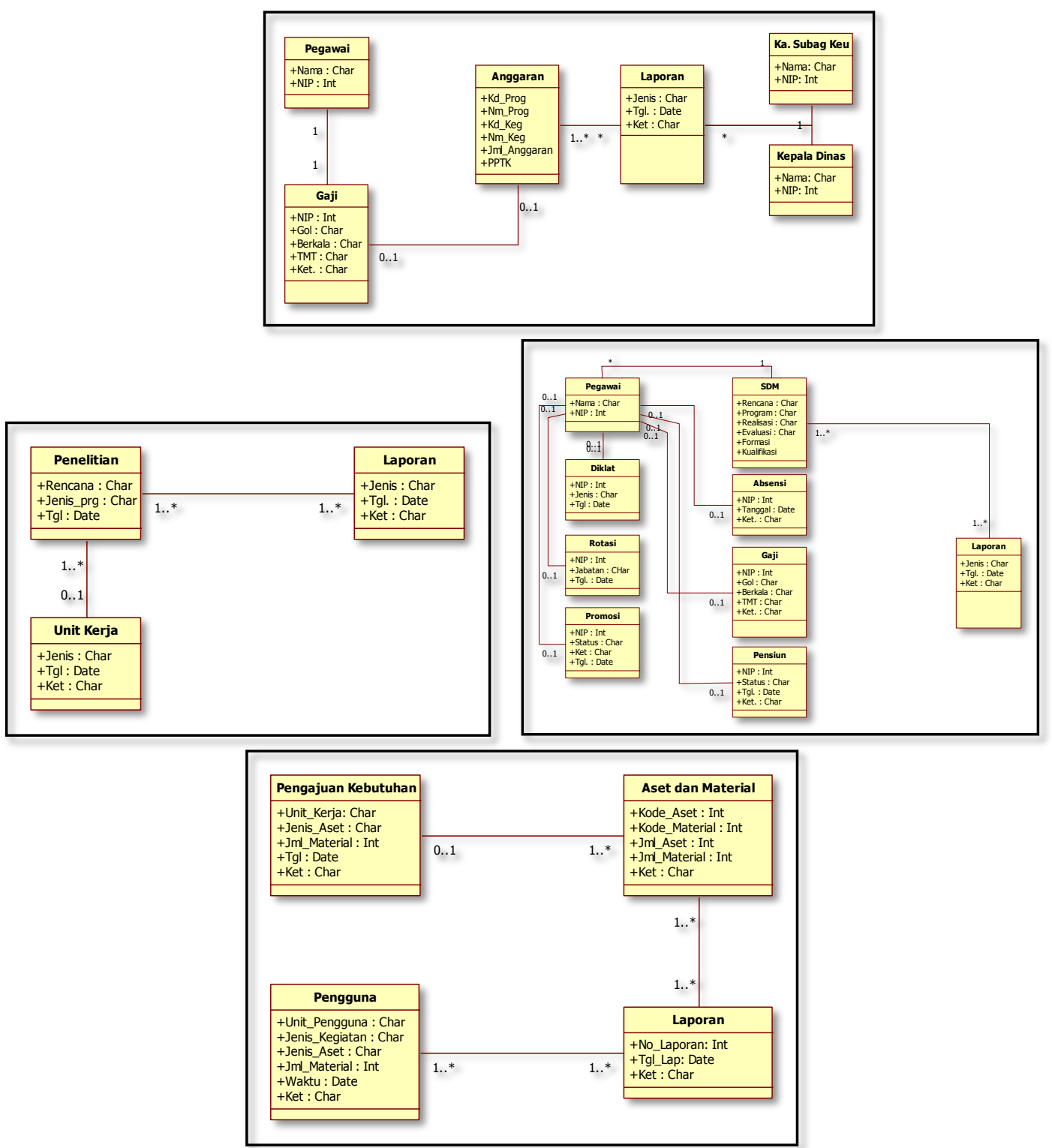


Gambar 9. Model Arsitektur Data Aktivitas Pendukung

\subsubsection{Model Arsitektur Aplikasi}

Tujuan arsitektur aplikasi untuk mendefinisikan aplikasi-aplikasi yang diperlukan untuk mengelola data dan mendukung fungsi-fungsi bisnis Dinas PUPR Kabupaten Indramayu. Pembuatan Model arsitektur aplikasi merupakan definisi tentang hal-hal yang dilakukan aplikasi untuk mengelola data dan menyediakan informasi bagi pelaksanaan fungsi-fungsi bisnis Dinas PUPR Kabupaten Indramayu.

Tahap pertama adalah dengan membuat daftar katalog aplikasi. Tujuan dari pembuatan katalog aplikasi (Application Portofolio Catalog ) ini adalah untuk mendefinisikan semua daftar aplikasi yang akan digunakan oleh Dinas PUPR Kabupaten Indramayu. Daftar katalog dibuat dalam bentik komponen diagram pada masing-masing fungsi bisnis.

Tabel 3. Katalog Rencana Aplikasi

\begin{tabular}{|c|l|l|}
\hline No. & \multicolumn{1}{|c|}{ Komponen Katalog } & \multicolumn{1}{c|}{ Rencana Aplikasi } \\
\hline 1. & Sistem Informasi Program/Kegiatan & Menentukan Program, Kegialatan, KPA dan PPTK. \\
\hline 2. & Sistem Infromasi Pengawasan Kegiatan & Pengawas, Laporan pengawasan / monitoring. \\
\hline 3. & Sistem Informasi Pelayanan Masyarakat & Permohonan Program/Kegaitan, Pekerjaan. \\
\hline 4. & Manajemen Keuangan & $\begin{array}{l}\text { Pengajuan Anggaran, Pembayaran Termin, } \\
\text { Administrasi Keuangan, Penggajian, Pelaporan. }\end{array}$ \\
\hline 5. & Manajemen Sumber Daya Manusia & $\begin{array}{l}\text { Pengelolaan SDM, Pengembangan SDM, } \\
\text { Administrasi Gaji, Mutasi, Promosi dan Kepangkatan, } \\
\text { Izin Cuti, Izin Belajar, Absensi, dan Pelaporan. }\end{array}$ \\
\hline 6. & Manajemen Teknologi Informasi & $\begin{array}{l}\text { Perencanaan Program Penelitian TI, Pemantauan dan } \\
\text { Evaluasi Pelaporan. }\end{array}$ \\
\hline 7. & Manajemen Aset & $\begin{array}{l}\text { Pengadaan, Pengajuan Kebutuhan, Pengelolaan Aset } \\
\text { dan Pelaporan. }\end{array}$ \\
\hline
\end{tabular}

Daftar katalog aplikasi yang telah didefinisikan diatas digunakan untuk tahapan selanjutnya yaitu dengan memetakan hubungan aplikasi dengan fungsi bisnis yang telah teridentifikasi pada Dinas PUPR Kabupaten Indramayu. Tujuan dari perbandingan ini adalah untuk mengidentifikasi fungsi-fungsi bisnis yang didukung secara langsung oleh aplikasi. Berikut fungsi matrik yang menunjukan hubungan aplikasi yang akan dibuat dengan fungsi-fungsi bisnis dinas. 
Tabel 4. Matrik Relasi Aplikasi Fungsi Bisnis Utama

\begin{tabular}{|c|c|c|c|c|c|c|c|c|c|c|c|c|}
\hline \multirow{2}{*}{\multicolumn{2}{|c|}{ FUNGSI }} & \multicolumn{11}{|c|}{ FUNGSI BISNIS UTAMA } \\
\hline & & \multicolumn{3}{|c|}{ Program/ Kegiatan } & \multicolumn{4}{|c|}{ Pengawasan / Monitoring } & \multicolumn{4}{|c|}{ Pelayanan } \\
\hline Program / Kegiatan & Dokumen Pelaksanaan Anggaran & & & & & & & & & & & \\
\hline \multirow{4}{*}{$\begin{array}{l}\text { Pengawasan / } \\
\text { Monitoring }\end{array}$} & Gambar dan RAB & & & & & & & & & & & \\
\hline & Laporan Harian & & & & & & & & & & & \\
\hline & Laporan Mingguan & & & & & & & & & & & \\
\hline & Laporan Bulanan & & & & & & & & & & & \\
\hline Pelayanan & Permohonan Kegiatan / Pekerjaan & & & & & & & & & & & \\
\hline
\end{tabular}

Keterangan:

Sudah menggunakan aplikasi

Belum menggunakan aplikasi

Tabel 5. Matrik Relasi Aplikasi Fungsi Bisnis Pendukung

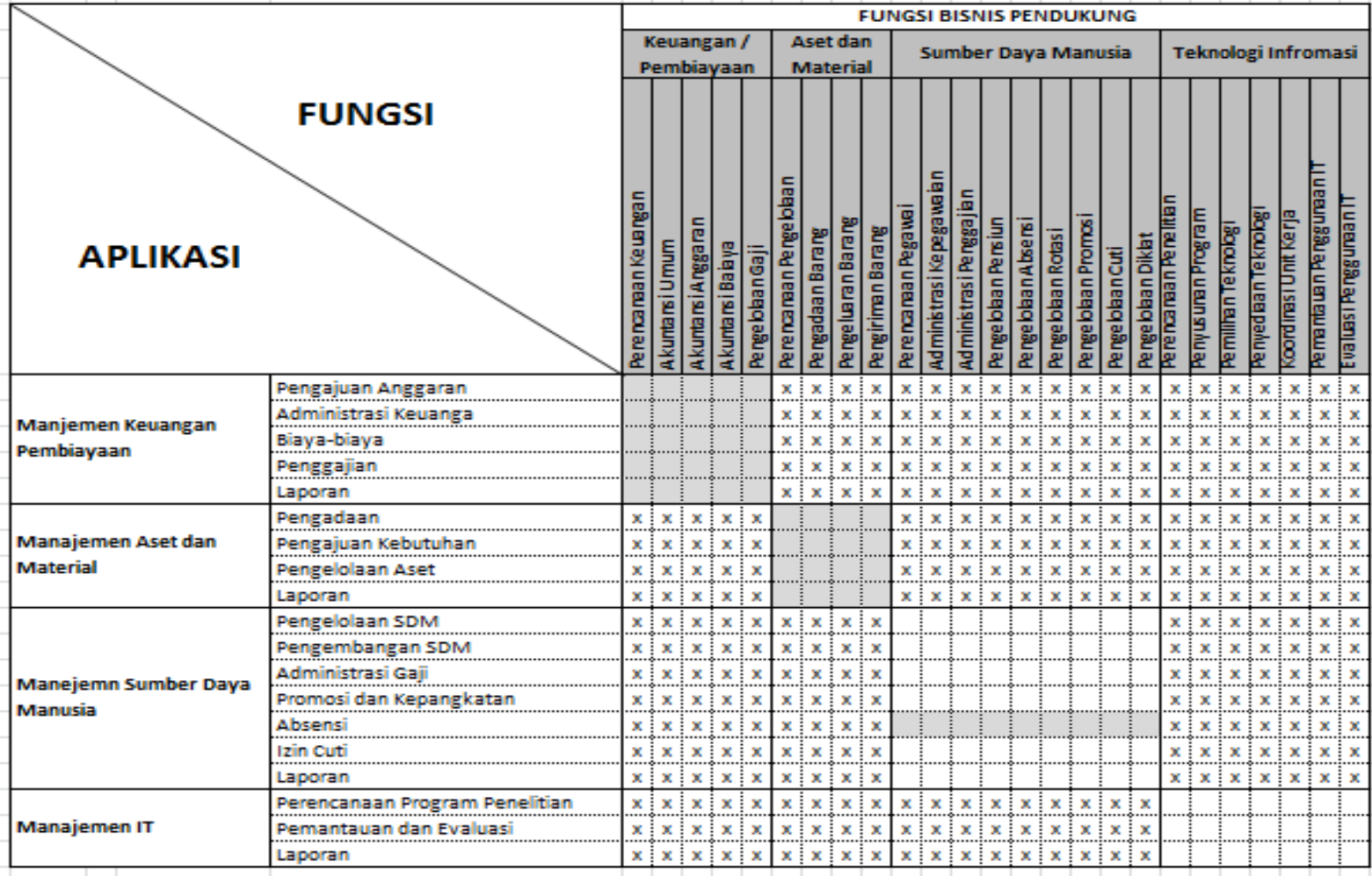

Keteranqan:

\begin{tabular}{|l|l}
\hline & Sudah menggunakan aplikasi \\
\hline & Belum menggunakan aplikasi
\end{tabular}

Setelah dilakukan pemetaan hubungan aplikasi dengan fungsi bisnis perusahaan, selanjutnya disusun suatu model komunikasi antar aplikasi dengan suatu diagram katalog 
komunikasi yang dapat menggambarkan hubungan antar aplikasi secara fisik maupun logis.

\subsection{Model Arsitektur Teknologi}

Mengacu kepada prinsip dasar arsitektur teknologi, penggunaan sistem operasi yang akan digunakan oleh Dinas PUPR Kabupaten Indramayu dapat menggunakan sistem operasi berbasis open source maupun sistem berlisensi yang mempunyai dukungan teknis dan aplikasi yang beroperasi pada sistem tersebut.

Manajemen data base yang akan digunakan dapat menggunakan MySQL Sybase atau Oracle. Aplikasi yang digunakan mempunyai dukungan sistem operasi yang luas. Sedangkan perangkat keras yang akan digunakan meliputi perangkat server, perangkat pengguna dan perangkat pendukung lainnya.

Komunikasi yang akan digunakan menggunakan service provider yang sesuai dengan kebutuhan. Sistem keamanan yang akan digunakan, keamanan jaringan (sistem firewall, autentikasi, otoritas, dan lain-lain), hak pakai pengguna aplikasi dan jaringan.

Prinsip dasar teknologi yang akan dipilih atau dikembangkan dengan harapan dapat memberikan kontribusi maksimal sesuai dengan fungsi bisnis perusahaan. Prinsip tersebut digambarkan pada gambar dibawah ini.

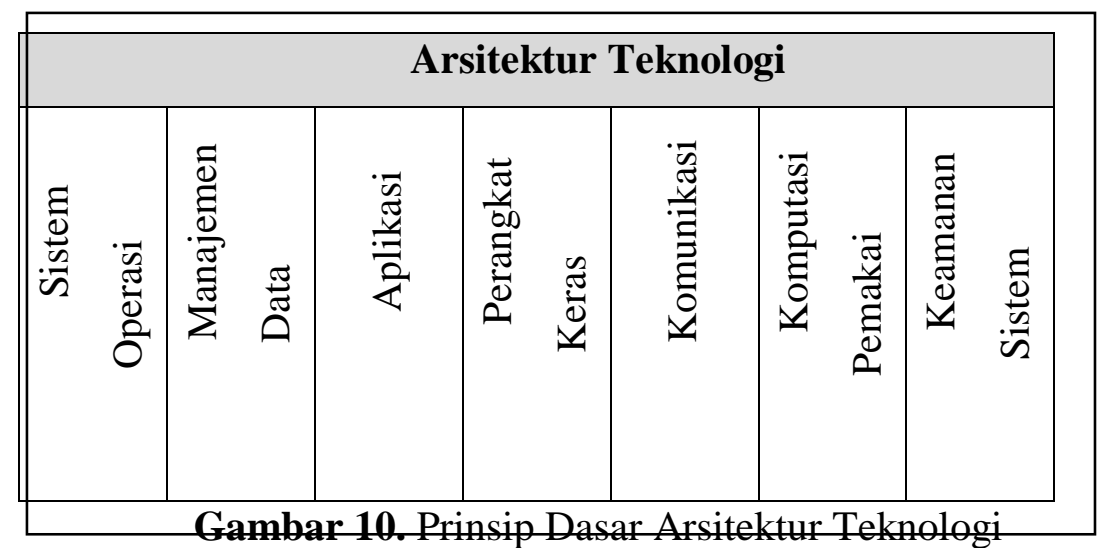

Konfigurasi jaringan konseptual sebagai bagian dari komunikasi data dan aplikasi yang akan diusulkan guna mendukung efektivitas pekerjaan semua unit, digambarkan dengan diagram network berikut : 


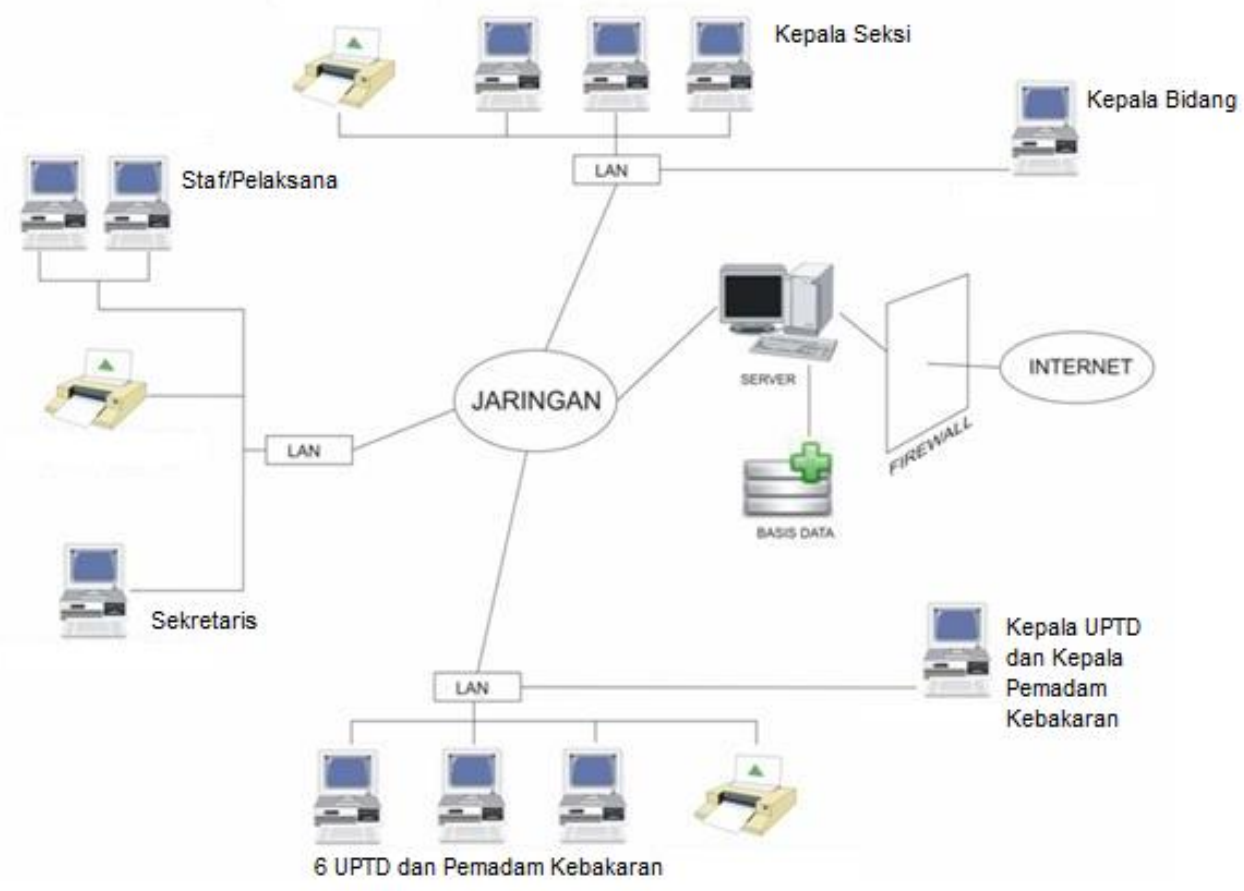

Gambar 11. Jaringan konseptual Sistem Informasi Pembangunan Infrastruktur

\subsection{Peluang dan Solusi}

Tahapan ini adalah tahap melakukan perencanaan terhadap peluang yang ada dengan mengidentifikasi kebutuhan pada tahapan-tahapan sebelumnya. Seiring dengan dinamika pengguna jaringan dan dengan kondisi yang semakin kompleks maka diperlukan kebutuhan infrastruktur jaringan yang dapat memberikan solusi efektif sehingga tujuan instansi dapat tercapai. Berikut ini adalah kebutuhan-kebutuhan terkait dengan infrastruktur jaringan Sistem Informasi Pembangunan Infrastruktur Dinas PUPR Kabupaten Indramayu.

Tabel 6. Kebutuhan dan Solusi Umum Jaringan Sistem Informasi

\begin{tabular}{|c|c|c|c|}
\hline No. & Kebutuhan & Analisis & Solusi \\
\hline 1. & Pengguna & $\begin{array}{l}\text { a. Volume data elektronik } \\
\text { yang besar. } \\
\text { b. Jaringan intranet dan } \\
\text { internet belum maksimal. }\end{array}$ & $\begin{array}{ll}\text { a. } & \text { Perlu dibagi menjadi } \\
& \text { beberapa subnet. } \\
\text { b. } & \text { Pemilihan topologi } \\
\text { jaringan yang mudah } \\
\text { dikembangkan untuk } \\
\text { mengantisipasi jumlah } \\
\text { pengguna. }\end{array}$ \\
\hline 2. & Akses Jaringan & $\begin{array}{l}\text { a. Akses jaringan belum } \\
\text { maksimal. } \\
\text { b. Infrastruktur jaringan } \\
\text { belum tertata dengan } \\
\text { baik. }\end{array}$ & $\begin{array}{ll}\text { a. } & \text { Titik akses pada intranet } \\
& \text { dilengkapi dengan jaringan } \\
& \text { kabel dan nirkabel. } \\
\text { b. } & \text { Penataan ulang arsitektur } \\
\text { jaringan. }\end{array}$ \\
\hline 3. & Penggunaan teknologi informasi & $\begin{array}{l}\text { a. Optimalisasi kegiatan } \\
\text { pengguna memerlukan }\end{array}$ & $\begin{array}{l}\text { a. Menyediakan server- } \\
\text { server dengan fungsi }\end{array}$ \\
\hline
\end{tabular}




\begin{tabular}{|c|c|c|c|}
\hline & & $\begin{array}{l}\text { dukungan TIK } \\
\text { b. Kekurangan kebutuhan } \\
\text { dan pengetahuan SDM } \\
\text { dibidang TI. }\end{array}$ & \begin{tabular}{|l} 
khusus agar kinerja server \\
menjadi optimal. \\
b. \\
cepses server harus lebih \\
cepat dengan topologi \\
jaringan yang \\
memungkinkan \\
penambahan server. \\
c. Melakukan pelatihan SDM \\
dibidang TI. \\
\end{tabular} \\
\hline 4. & $\begin{array}{l}\text { Komunikasi dan resources } \\
\text { sharing yang berformat } \\
\text { multimedia. }\end{array}$ & $\begin{array}{l}\text { Jaringan belum mendukung } \\
\text { transmisi data dalam } \\
\text { kecepatan tinggi. }\end{array}$ & $\begin{array}{l}\text { Jaringan yang mendukung } \\
\text { transmisi data dalam } \\
\text { kecepatan tinggi. }\end{array}$ \\
\hline 5. & Akses komunikasi dan informasi & $\begin{array}{l}\text { Akses informasi sebagian } \\
\text { belum bisa diakses secara } \\
\text { menyeluruh } \\
\text { o. Koneksi ke jaringan } \\
\text { internet dengan kecepatan } \\
\text { tinggi belum maksimal }\end{array}$ & $\begin{array}{ll}\text { a. } & \text { Pemisahan aplikasi yang } \\
& \text { menyediakan akses } \\
\text { informasi restriktif dalam } \\
\text { jaringan khusus. } \\
\text { b. } \\
\text { Koneksi ke jaringan } \\
\text { internet dengan kecepatan } \\
\text { tinggi }\end{array}$ \\
\hline 6. & $\begin{array}{l}\text { Keamanan dan proteksi data, } \\
\text { infromasi }\end{array}$ & $\begin{array}{l}\text { Belum terjaminnya } \\
\text { keamanan dan proteksi data } \\
\text { dari gangguan akif dan pasif }\end{array}$ & $\begin{array}{l}\text { Menerapkan manajemen } \\
\text { keamanan jaringan yang } \\
\text { handal (fisik,sistem operasi } \\
\text { dan aplikasi jaringan). }\end{array}$ \\
\hline
\end{tabular}

\subsection{Perencanaan Migrasi}

Tahapan migrasi disusun berdasarkan prioritas dan interdepedensi antar sistem. Salah satu hasil yang diperoleh dari arsitektur aplikasi adalah bagaimana sebuah data atau kumpulan data dideskripsikan oleh aplikasi. Rencana migrasi sistem informasi dapat juga dilakukan dengan matrik penilaian aplikasi. Pemodelan yang digunakan pada tahapan ini menggunakan matrik penilaian dan keputusan terhadap kebutuhan utama dan pendukung sistem informasi.

Pada matrik penilaian dan kebutuhan aplikasi dibuat daftar kebutuhan pada kolom sistem aplikasi yang akan digunakan. Kolom penilaian terdiri dari 3 entitas kolom. Kolom penilaian entitas 1 mengambarkan bahwa sistem belum dibutuhkan atau sistem telah ada dan masih digunakan, belum ada rencana perbaikan atau penggantian sistem baru. Kolom penilaian entitas 2 digunakan untuk sistem yang memerlukan perbaikan atau disesuaikan dengan peningkatan kebutuhan organisasi. Sedangkan kolom penilaian 3 diasumsikan bahwa perlu dibuat sistem baru. Penilaian dilakukan karena sistem tersebut belum ada atau sudah ada, akan tetapi harus diganti dengan sistem yang baru. 
Setelah dipetakan berdasarkan prinsip dasar arsitektur teknologi, diperoleh adanya manfaat dari penerapan sistem informasi dengan menggunakan teknologi yang tepat sesuai dengan kebutuhan, sehingga dapat mendukung efektivitas dan efisiensi pekerjaan pada masing-masing unit kerja.

\section{KESIMPULAN}

Setelah melakukan penelitian berkaitan dengan perencanaan Arsitektur Sistem Informasi pembangunan infrastruktur Dinas PUPR Kabupaten Indramayu dan berdasarkan hasil pembahasan yang telah disampaikan sesuai dengan tahapan penelitian, dapat ambil beberapa kesimpulan sebagai berikut :

1. Dinas PUPR Kabupaten Indramayu adalah pengelola Sistem Informasi Pembangunan Infrastruktur merupakan instansi pemerintahan yang membidangi infrastruktur/konstruksi bangunan dan gedung yang dituntut memberikan pelayanan yang efektif dan efisien. Manfaat Enterprise Architecture (EA) Sistem Informasi sebagai landasan pengembangan yang tidak keluar dari tujuan perusahaan dan tidak menghilangkan integrasi antar bidang/Unit Pelaksana Teknis.

2. Kerangka kerja TOGAF (The Open Group Arsitektur) digunakan untuk memodelkan Enterprise Architecture. TOGAF menawarkan metode dan alat bantu yang lengkap untuk implementasi EA. Salah satu kelebihan menggunakan kerangka kerja TOGAF adalah karena sifatnya yang fleksibel dan bersifat open source.

3. Alat bantu UML (Unified Modeling Language) digunakan dalam pemodelan arsitektur bisnis sehingga identifikasi aktivitas bisnis yang ada dapat digambarkan secara jelas. Pemodelan arsitektur bisnis menggunakan use case package diagram digunakan untuk identifikasi fungsi bisnis utama dan fungsi bisnis pendukung.

4. Pemodelan arsitektur data untuk arsitektur Sistem Informasi Pembangunan Infrastruktur Dinas PUPR Kabupaten Indramayu menggunakan class diagram berdasarkan penentuan entitas fungsi bisnis pada model arsitektur bisnis.

5. Pemodelan arsitektur aplikasi dengan membuat daftar katalog aplikasi (Application Portfolio Catalog) yang bertujuan untuk mendefinisikan semua daftar aplikasi yang digunakan. Model arsitektur dibangun untuk mendefinisikan kebutuhan teknologi dalam pengolahan data dan pengoperasian aplikasi.

\section{DAFTAR PUSTAKA}

Buckl, S., Ernst, A.M., Matthes, F., Ramacher, R., Schweda, C.M. 2009. Using Enterprise Architecture Management Patterns to Complement TOGAF. IEEE International Enterprise Distributed Object Computing Conference (EDOC'09). 
Harrison, R. 2007. TOGAF Version 8.1.1 Enterprise Edition Study Guide, New York: Van Haren Publishing.

Kourdi, H.S. 2007. Framework for Enterprise Architecture, IEEE.

Laudon, K C., and Laudon, J P. 2011. Management Information System: Managing the Digital Firm, 12th Edition. New Jersey: Prentice Hall.

Mutyarini, K. \& Sembiring, J. 2006, Arsitektur Sistem Informasi untuk Institusi Perguruan Tinggi di Indonesia, Prosiding KNTI \& K. pp102-107.

Osvalds, G. 2001. Definition od Enterprise Architecture - Centric Models for The Systems Engineers. TASC Inc.

Quartel, D., Engelsman, W., Jonkers, H., van Sinderen, M. 2009. A Goal-Oriented Requirements Modelling Language for Enterprise Architecture. IEEE International Enterprise Distributed Object Computing Conference (EDOC’09).

Spewak \& Steven H.C. 1992. Enterprise Architecture Planning : Developing Blue Print for Data, Application, and Techonologi. Jhon Willey \& Sons.

The Open Group. 2007. "The Open Group Architecture Framework (TOGAF), Version 8.1.1, Enterprise Edition. (Evaluation Copyright).

Ward, J., and Peppard, J. 2002. Strategic Planning For Information System. 3rd Edition. Chichester: John Willey \& Sons, Buffins Lane. 